\title{
EFFECTS OF IN VITRO MATURATION MEDIA ON IN VITRO FERTILITY OF PORCINE OOCYTES AND EARLY DEVELOPMENT OF EMBRYOS
}

\author{
Nguyen Viet Linh ${ }^{1,2, \bowtie}$, Nguyen Thi Hiep ${ }^{1}$ \\ ${ }^{I}$ Institute of Biotechnology, Vietnam Academy of Science and Technology \\ ${ }^{2}$ Graduate University of Science and Technology, Vietnam Academy of Science and Technology \\ ${ }^{凶}$ To whom correspondence should be addressed. E-mail: nvlinh@ibt.ac.vn
}

Received: 27.4 .2020

Accepted: 22.6.2020

\section{SUMMARY}

In pigs, embryo productivity is still lower than that in other livestocks. One of the reasons is incomplete maturation of porcine oocytes in in vitro conditions. Therefore in vitro maturation (IVM) plays a crucial role in in vitro production of porcine embryos. It provides prerequisite condition to in fertilization and subsequent development of porcine embryos. In a previous study, effects of NCSU-37-based medium and TCM-199-based media supplemented with porcine follicular fluid $(\mathrm{pFF})$ or Fetal Bovine Serum (FBS) on in vitro maturation of Landrace oocytes collected in Vietnam have been compared, suggesting that NCSU-37 medium supplemented with $10 \%$ of porcine follicular fluid $(\mathrm{pFF})$ had the highest rate of oocytes reach to metaphase II stage in comparison to those of the other two TCM-199-based media. In the present study, further experiments were carried out to evaluate the contribution of IVM media on fertilization capability and developmental competence. Porcine oocytes matured in vitro in 3 media: NCSU-37 supplemented with $10 \% \mathrm{pFF}$, TCM-199 supplemented with either $10 \% \mathrm{pFF}$ or $10 \%$ FBS were subjected to in vitro fertilization and subsequent in vitro culture to monitor fertility and embryo development. The results showed that penetration and normal fertilization rates in both TCM-199 groups are both higher than that of NCSU-37 group. Moreover, the cleavage and blastocyst rates, and cell numbers of blastocysts which is a criterion for embryo quality were all higher in TCM-199 groups, especially in the group supplemented with pFF. It might be concluded that TCM-199 media supplemented with either $\mathrm{pFF}$ or FBS are suitable for effective in vitro maturation of Landrace porcine oocytes collected in Vietnam.

Keywords: in vitro maturation, TCM-199, NCSU-37, pFF, FBS, in vitro fertilization, embryo development

\section{INTRODUCTION}

In vitro maturation and in vitro fertilization has been successful since 1989s with piglets produced from IVM and IVF of porcine oocytes (Mattioli et al., 1989). However, incomplete maturation of porcine oocytes in culture led to low embryo productivity in this species (Nagai et al., 2006). Many researches were carried out to address this issue (Kątska-Książkiewicz, 2006), including testing of many medium systems and supplementation of necessary substances in order to improve the oocyte's situation after culture, in order to achieve better fertilization and embryo development (Nagai, 2001). Systems based on Tyrode's albumin lactate pyruvate medium (TALP) (Yoshida et al., 1992), Tissue Culture Medium 199 - TCM 199 (Abeydeera and Day, 1997), North Carolina State University (NCSU) containing either taurine and hypotaurine (NCSU-23) (Li et al., 2004; Margot et al., 2001) or sorbitol - NCSU- 
37 (Kikuchi et al., 2002; Yoshioka et al., 2003) were developed and all have achieved higher and higher fertilization rates, higher blastocyst rates and/or success of embryo transfer.

Supplementation of substances could contribute effectively to maturation of porcine oocytes. Supplementation of hormones helps significantly increase in vitro maturation rates as well as penetration of sperm into oocytes and rates of embryos reached to blastocyst stage (Funahashi and Day, 1989; Suzuki et al., 2003). In vitro maturation rates varied by culture media, NCSU-23 could achieve a rate of 33.0-93.1\% depends on oocyte quality (Quian et al., 2001), NCSU-37 up to $90.5 \%$ (Spinaci et al., 2008); TCM 199, Waymouth, mTLP-PVA, they were $61 \%, 64 \%, 70 \%$, respectively, however, with pFF supplementation much better improvement could be revealed $(92,94$ and $88 \%$, respectively) (Yoshida et al., 1992). Criteria of fertilization and embryo development, in general, are in proportional to maturation rates (Funahashi and Day, 1989; Quian et al., 2001; Suzuki et al., 2003; Kikuchi et al., 2002; Yoshioka et al., 2003). pFF supplementation contribute to expansion of cumulus cells and ooplasmic maturation, therefore fertilization is more well-prepared and more embryos could reach to higher stage of development (Kikuchi et al., 2002; Marchal et al., 2001; Yoshioka et al., 2003).

In Vietnam, in vitro maturation and in vitro fertilization have been deployed since the 2000s (Nguyen, 2003; Duyen et al., 2003). Effects of many factors, such as season, hormone supplementation, sperm concentration, feeder cell co-culture, etc. on IVM and IVF of porcine oocytes have been studied (Duyen et al., 2003; Uoc et al., 2008; Hiep et al., 2014). Recently, Nguyen et al. (2015) while comparing maturation of Ban oocytes, could achieve a rate of $78.6 \%$ maturation in Landrace oocytes in NCSU-37 medium without hormone. However, the research did not survey on fertilization criteria. In a previous study, we evaluated IVM efficiency with 3 media: NCSU-37 supplemented with $10 \%$ of porcine follicular fluid (pFF) (Group 1 - control), TCM 199 supplemented with either $10 \%$ fetal bovine serum (FBS) (Group 2) or 10\% pFF (Group 3). The results showed that Group 1 had the highest rate of oocytes reach to metaphase II stage in comparison to the other two groups, the rate of MII oocytes of TCM 199 supplemented with $\mathrm{pFF}$ is higher than that supplemented with FBS (Hiep et al., 2018). In the present study, we continue to compare the three medium formulas in the aspect of support to in vitro fertilization and embryo development.

\section{MATERIALS AND METHODS}

\section{Oocyte collection}

Oocytes were collected as previously described (Kikuchi et al., 2002, Hiep et al. 2018). Briefly, ovaries were collected from Landrace sows at a slaughter house in the suburb of Hanoi, rinsed and transported to the laboratory in physiological saline solution $(0.9 \% \mathrm{NaCl})$ with antibiotics at $35^{\circ} \mathrm{C}$. The ovaries were rinsed several times in PBS and cumulus oocytes complexes (COCs) were aspirated from ovarian follicles using a scalpel blade. COCs were selected in TCM-199 medium with Hanks' salts supplemented with 5\% FBS, $20 \mathrm{mM}$ HEPES, $100 \mathrm{IU} / \mathrm{mL}$ penicillin $\mathrm{G}$ potassium and $0.1 \mathrm{mg} / \mathrm{mL}$ streptomycin sulfate under a stereo microscope. COCs having 2 uniform layers of cumulus cells and a homogenous cytoplasm were selected for subsequent in vitro maturation.

\section{In vitro maturation}

Oocytes were randomLy divided into 3 groups of approximately 30-35 oocytes and cultured in 4-well dish containing $500 \mu \mathrm{L}$ of maturation media supplemented with $0.6 \mathrm{mM}$ cysteine, $50 \mu \mathrm{M} \quad \beta$-mercaptoethanol ( $\beta$-ME), $10 \mu \mathrm{g} / \mathrm{mL}$ FSH and $\mathrm{LH}$, and $1.0 \mathrm{mmol} / \mathrm{L}$ dibutyryl cyclic adenosine monophosphate (dbcAMP) at 390C, $5 \% \mathrm{CO} 2,5 \% \mathrm{O} 2,90 \% \mathrm{~N} 2$ in humidified air.

Group 1: COCs were cultured in NCSU-37 medium supplemented with $10 \% \mathrm{pFF}$. 
Group 2: COCs were cultured in TCM-199 medium supplemented with $10 \% \mathrm{pFF}$.

Group 3: COCs were cultured in TCM-199 medium supplemented with $10 \%$ FBS.

After 20-22 hours, COCs in groups were then transferred into other disks containing the same medium but without hormones and dbcAMP for a further culture of 22-24 hours, before subjected to in vitro fertilization.

\section{In vitro fertilization and embryo culture}

In vitro fertilization and in vitro embryo culture (IVC) procedures were performed as described by Kikuchi et al. (2002). Briefly, COCs after IVM were washed and transferred into $90 \mu \mathrm{L}$ drops of Pig-FM medium in cell culture disks covered with mineral oil. Epididymal sperms, collected and frozen as previously described (Hiep et al., 2014), were washed, centrifuged and activated at $37^{\circ} \mathrm{C}$ for 15 minutes in sperm washing medium (TCM199 with Earle's salts, $\mathrm{pH}$ adjusted to 7.8) in a 30-mm petri dish, covered by paraffin oil. A suitable volume of sperms were diluted in PigFM medium after determining the concentration of sperm. $10 \mu \mathrm{L}$ of the correspondent sperm dilution was introduced into the $90-\mu \mathrm{L}$ IVF droplets containing the oocytes to a final concentration of $10^{6}$ sperm $/ \mathrm{mL}$ and coincubated at $39^{\circ} \mathrm{C} 38.5^{\circ} \mathrm{C}$ under $5 \% \mathrm{CO}_{2}$ for 3 hours. At the end of IVF, spermatozoa and cumulus cells were removed from the surface of the zona pellucida by gentle pipetting with a fine glass pipette. Then, oocytes were either fixed for evaluation of fertilization, or cultured for $10 \mathrm{~h}$ in $500-\mu \mathrm{L}$ drops of IVC-PyrLac and IVC-Glu for 2 and 4 days, respectively (Kikuchi et al. 2002) in 4-well dishes in an atmosphere of $5 \% \mathrm{CO} 2$, in air at $38.5^{\circ} \mathrm{C}$. At day 2 and day 6 of in vitro culture (day of fertilization is defined as day 0), embryos were recorded for ones which could reach to cleavage and blastocyst stage (after checking by fixation, staining and cell number count), respectively.

\section{Evaluation of fertilization}

The fertilization status of oocytes was assessed 10 hours after IVF. Oocytes were mounted on glass slides and fixed with acetic alcohol (acetic acid 1: ethanol 3) for at least 5 days, stained with $1 \%(\mathrm{w} / \mathrm{v})$ orcein in acetic acid, rinsed in glycerol : acetic acid : water $(1: 1: 3)$ and then examined under a phasecontrast microscope. The status of oocyte chromatin, the presence and numbers of female and male pronuclei and/or sperm head(s) and existence of the first and second polar bodies (1PB and $2 \mathrm{~PB}$, respectively) were investigated in the oocytes. Number of oocytes with penetration, ones which could form male pronuclear (MPN), and ones with normal fertilization defining as appearance of one female pronuclear, one male pronuclear, and two extruded polar body (Figure 1A), were recorded.

\section{Evaluation of blastocyst quality by blastomere number}

All embryos were fixed on glass slides at day 6 of culture in fixative containing ethanol : acid acetic with a ratio of $3: 1(\mathrm{v} / \mathrm{v})$ for $3-4$ days. Embryos were then stained with $1 \%(\mathrm{w} / \mathrm{v})$ orcein in acetic acid, rinsed in glycerol : acetic acid : water (1:1:3). Blastomere numbers are counted by the cells nuclear which were stained red with orcein under phase contrast microscope. With each embryo, cell number was counted for 3 times and an average number of those times was used as the final result. An embryo was considered a blastocyst when it had more than 10 cells and a visible blastocoel in the cavity of it (Figure 1B).

\section{Statistical analysis}

Data were expressed as number and percentages were under the form of mean \pm SEM values. Data were analyzed by one-way ANOVA on MS Excel Software.

\section{RESULTS AND DISSCUSSION}

Effects of in vitro maturation media to fertilization status of porcine oocytes are shown in Table 1. Rates of penetration, MPN formation in groups matured in TCM-199 with $\mathrm{pFF}$ and TCM-199 with FBS were 50.3\% and 49.3\%, and 
$94.8 \%$ and $97.1 \%$, respectively, higher than those of NCSU-37 $(25.4 \%$ and $69.8 \%)(\mathrm{P}<0.05)$. There was no significant difference between the two TCM-199 formulas in penetration and MNP formation rates $(\mathrm{P}>0.05)$.

In TCM-199 with FBS group, normal fertilization rate was higher than that of group matured in TCM-199 with $\mathrm{pFF}(66.2 \%$ vs. $58.4 \%, \mathrm{P}<0.05)$. In the meanwhile, normal fertilization rate of NCSU-37 was only $37.2 \%$, significantly lower than those of the other groups $(\mathrm{P}<0.05)$.

Wang et al., (1997) carried out a study in which the penetration rates of oocytes matured in NCSU-23, TCM-199 and mWM media were higher than in our study $(71,76$, and $74 \%$, respectively). However, MPN formation rates are equal to our study's (92, 83 , and $86 \%$, respectively). No difference was found between media and supplementation. Penetration and normal fertilization rates are much higher than those in our study. It might be because of differences in ovary sources between the two researches. In Vietnam, sows are usually slaughtered at a younger age than ones in developed countries, making ovaries collected at an earlier stage of maturation.

Besides fertilization status, we also checked the developmental competence of embryos produced from oocytes cultured in different medium formulas. The results are shown in Table 2. Cleavage rates were higher in TCM199 groups than in NCSU-37 group (50.0\%, and one supplemented with $\mathrm{pFF}$ was higher than one with FBS $(74.0 \%$ vs. $70.0 \%)$. Blastocyst rates of Groups 1, 2 and 3 were $6.3 \%, 13.4 \%$, and $19.6 \%$ ), in which TCM-199 showed a significant advantage in formation of blastocyst in compare to NCSU-37, and FBS supplementation showed a significant advantage to $\mathrm{pFF}$ supplementation.

Table 1. Effects of in vitro maturation media to fertilization status of porcine oocytes

\begin{tabular}{llllll}
\hline Group & Culture medium & $\begin{array}{l}\text { Total } \\
\text { number of } \\
\text { oocytes }\end{array}$ & $\begin{array}{l}\text { Number (\%) of } \\
\text { oocytes with } \\
\text { penetration }\end{array}$ & $\begin{array}{l}\text { Number (\%) of } \\
\text { oocytes with } \\
\text { MPN }\end{array}$ & $\begin{array}{l}\text { Number (\%) of } \\
\text { normal } \\
\text { fertilization }\end{array}$ \\
\hline 1 & NCSU-37 with 10\% pFF & 158 & $43(25.4 \pm 2.6)^{\mathrm{b}}$ & $30(69.8 \pm 8.0)^{\mathrm{b}}$ & $16(37.2 \pm 6.2)^{\mathrm{c}}$ \\
2 & TCM-199 with 10\% pFF & 94 & $68(49.3 \pm 2.7)^{\mathrm{a}}$ & $66(97.1 \pm 2.0)^{\mathrm{a}}$ & $45(66.2 \pm 6.4)^{\mathrm{a}}$ \\
3 & TCM-199 with 10\% FBS & 78 & $77(50.3 \pm 7.4)^{\mathrm{a}}$ & $73(94.8 \pm 4.7)^{\mathrm{a}}$ & $45(58.4 \pm 4.5)^{\mathrm{b}}$ \\
\hline
\end{tabular}

5 replications were performed. Superscripts in the same column indicate significance $(P<0.05)$.

Table 2. Effects of in vitro maturation media to development of in vitro produced porcine embryos

\begin{tabular}{llllll}
\hline Group & Culture medium & $\begin{array}{l}\text { Total } \\
\text { number of } \\
\text { oocytes }\end{array}$ & $\begin{array}{l}\text { Number (\%) of } \\
\text { cleavage }\end{array}$ & $\begin{array}{l}\text { Number (\%) of } \\
\text { blastocyst }\end{array}$ & $\begin{array}{l}\text { Cell number of } \\
\text { blastocysts }\end{array}$ \\
\hline 1 & NCSU-37 with 10\% pFF & 158 & $79(50.0 \pm 3.5)^{b}$ & $10(6.3 \pm 1.0)^{\mathrm{c}}$ & $(18.5 \pm 2.3)^{\mathrm{b}}$ \\
2 & TCM-199 with 10\% pFF & 253 & $187(74.0 \pm 3.2)^{\mathrm{a}}$ & $34(13.4 \pm 1.9)^{\mathrm{b}}$ & $(28.5 \pm 1.6)^{\mathrm{a}}$ \\
3 & TCM-199 with 10\% FBS & 266 & $186(70.0 \pm 6.8)^{\mathrm{a}}$ & $52(19.6 \pm 1.2)^{\mathrm{a}}$ & $(31.7 \pm 1.5)^{\mathrm{a}}$ \\
\hline
\end{tabular}

5 replications were performed. Superscripts in the same column indicate significance $(P<0.05)$. Cell number is performed as mean \pm SEM. 
Similarly in Wang et al. (1997), effects of in vitro maturation media on development of porcine embryos were also studied. Oocytes matured in NCSU-23, TCM-199 and mWM were in vitro fertilized and cultured. At 48 hour post insemination (h.p.i), cleavage rates reached 6170\% (NCSU-23: 70\%, TCM-199 and mWM: $61 \%$ ), which were equal to that of the present study. At day 6 of embryo culture, blastocyst rate of group using NCSU-23 medium were significantly higher than those in TCM-199 and mWM $(27 \%, 15 \%$, and 4\%, respectively). Average cell number in each groups were 36.8, 30.7 , and 29.4, respectively. NCSU-23 showed advantages in both blastocyst rate and cell number in compare to TCM-199 and mWM. NCSU-23, a little different version of NCSU-37, was a popular medium for in vitro maturation applying in many previous researches (Abeydeera and Day, 1997; Karja, 2008; Suzuki et al., 2003). The results in our study were in contrast of that previous study, in which TCM-199 medium and FBS supplementation showed a better contribution to development of embryos to cleavage and blastocyst stages. Average cell numbers in the present study are not significant between groups, and all is similar and even more stable to those in Wang et al. (1997).

In the previous study, we had shown that NCSU-37 contributed better to in vitro maturation of Landrace porcine oocytes than TCM-199 supplemented with either pFF or FBS (Hiep et al., 2018). However, the results in this study showed that better maturation, in the form of completion of first meiosis, did not in accordance with fertility, in the form of penetration, MPN formation and normal fertilization, and development competence, in the form of cleavage, blastocyst formation, and blastocyst cell number. TCM-199 group had higher criteria of fertilization and development in compare to NCSU-37, and FBS supplementation was equal to better than $\mathrm{pFF}$ supplementation. FBS and pFF both have their own advantages and disadvantages. With $\mathrm{pFF}$, it is cheap and easy to harvest, however, it is complicated to be treated and to be kept from contamination. With FBS, it is commonly used in cytology and embryology with commercialized various products, however, it is rather more expensive than $\mathrm{pFF}$.

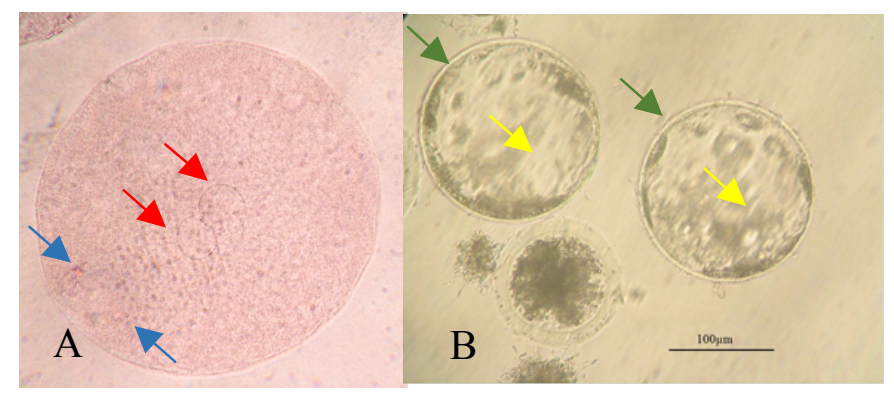

Figure 1. (A) A normally fertilized oocyte at 400X magnification with a male pronuclear, a female pronuclear (red arrows), and two polar body extruded (blue arrows); and (B) porcine embryos at blastocyst stages (green arrows) with blastocoels (yellow arrows).

\section{CONCLUSION}

TCM-199 medium for maturation contribute to penetration, fertilization and subsequent embryo production better than NCSU-37 medium. Embryos produced by oocytes cultured in maturation medium supplementation with FBS could reach to blastocyst stage with a higher rate than that with $\mathrm{pFF}$.

Acknowledgement: The authors would like to thank the colleagues of the Laboratory of Embryo Technology, IBT, for assisting in experiments. The study is funded by Vietnam 
National Foundation for Science and Technology Development (NAFOSTED) under grant number 106-NN.01-2015.59.

\section{REFERENCES}

Abeydeera LR, Day BN (1997) Fertilization and subsequent development in vitro of pig oocytes inseminated in a modified Tris-buffered medium with frozen-thawed ejaculated spermatozoa. Biol Reprod 57: 729-734.

Duyen HTL, Ngoc PK, Duong HHT, Dat NQ (2003) Application of in vitro fertilization technique on pigs. Proc Vietnam Nat Conf Biotech: 639-642.

Funahashi H, Day BN (1993) Effects of the duration of exposure to hormone supplements on cytoplasmic maturation of pig oocytes in vitro. $J$ Reprod Fertil 98: 179-185.

Hiep NT, Thinh NH, Hanh NV, Viet Linh N (2018) Comparison of in vitro maturation of porcine oocytes using different maturation media. $J$ Sci Tech Husbandry 232: 78-82.

Hiep NT, Uoc NT, Mai HN, Viet Linh N (2014) The effect of frozen sperm factor on developmental competence of porcine oocytes matured and fertilized in vitro. Thai Nguyen Univ J Sci Tech 123: 101-106.

Karja NWK (2008) Nuclear Maturation of Porcine oocytes in vitro: Effect of the Cumulus-Oocyte Complexes Quality. Indonesian J Biotech 13: 10781084.

Kątska-Książkiewicz L (2006) Pig embryo production by in vitro maturation and fertilization of ovarian oocytes. A review. J Anim Feed Sci 15: 525542.

Kikuchi K, Onishi A, Kashiwazaki N, Iwamoto M, Noguchi J, Kaneko H, Akita T, Nagai T (2002) Successful piglet production after transfer of blastocysts produced by a modified in vitro system. Biol Reprod 66: 1033-1041.

Li Q, Niwa K, Hunter MG (2004) Effects of 17 betaestradiol on in vitro maturation of pig oocytes in protein-free medium. $J$ Reprod Dev 50: 305-313.

Margot A, Nunes D, Charles G (2001) Influence of hormones and follicular fluid on maturation of pig oocytes. Ciênca Rural, Santa Maria, 31 (1): 99-104.
Mattioli M, Bacci mL, Galeati G, Seren E (1989) Developmental competence of pig oocytes matured and fertilized in vitro. Theriogenology 31: 12011207.

Nagai $T$ (2001) The improvement of in vitro maturation systems for bovine and porcine oocytes. Theriogenology 55: 1291-1201.

Nagai T, Funahashi H, Yoshioka K, Kikuchi K (2006) Update of in vitro production of porcine embryos. Front Biosci 11: 2565-2573.

Nguyen BX (2003) Development of embryo and embryonic cell technology in Vietnam. Proc Inst Biotech: 411-417.

Nguyen BX, Kikuchi K, Uoc NT, Dang-Nguyen TQ, Linh NV, Men NT, Nguyen TT, Nagai T (2015) Production of Ban miniature pig embryos by in vitro fertilization: a comparative study with Landrace. Anim Sci J 86: 487-493.

Qian Y, Shi WQ, Ding JT, Fan BQ, Fuku Y (2001) Effect of follicle size on Cumulus - Expansion, In vitro fertilization and development of porcine follicular oocytes. J Reprod Dev 47: 145-152.

Spinaci M, Volpe S, De Ambrogi M, Tamanini C, Galeati G (2008) Effects of epigallocatechin-3gallate (EGCG) on in vitro maturation and fertilization of porcine oocytes. Theriogenology 69: 877-885.

Suzuki H, Saito Y, Kagawa N and Yang X (2003) In vitro Fertilization and Polyspermy in the Pig: Factors Affecting Fertilization Rates and Cytoskeletal Reorganization of the Oocyte. Microsc Res Tech 61: 327-334.

Uoc NT, Ty LV, Duc NH, Chi BL, Thanh NT, Linh NV, Hanh NV, Huu QX, Anh NT, Son HN, Long DD, Nguyen BX (2003) "Production of dairy calves by in vitro fertilization and transfer of sex predetermined embyos. Proc Vietnam Nat Conf Biotech: 717- 719.

Wang WH, L Abeydeera R, Cantley TC, Day BN (1997) Effects of Oocyte maturation media on development of pig embryos produced by in vitro fertilization. J Repro Fertility 111: 101-108.

Yoshida M, Ishigaki K, Pursel VG (1992) Effect of maturation media on male pronucleus formation in pig oocytes matured in vitro. Mol Reprod Dev 31: $68-71$. 
Yoshioka K, Suzuki T, Tanaka A, Anas IMK, Iwamura S (2003) Birth of piglets derived from

porcine zygotes cultured in a chemically defined medium. Biol Reprod 66: 112-119.

\title{
ẢNH HƯỞNG CỦA MÔI TRƯờnG NUÔI THÀNH THỤC LÊN KHẢ NĂNG THỤ TINH ỐNG NGHIỆM CỦA TRÚNG LỘN VÀ SỰ PHÁT TRIỂN PHÔI SỚM
}

\author{
Nguyễn Việt Linh ${ }^{1,2}$, Nguyễn Thị Hiệp ${ }^{1}$ \\ ${ }^{1}$ Viện Công nghệ sinh hoc, Viện Hàn lâm Khoa hoc và Công nghệ Việt Nam \\ ${ }^{2}$ Hoc viện Khoa học và Công nghệ, Viện Hàn lâm Khoa học và Công nghệ Việt Nam
}

\section{TÓM TẮT}

Hiệu suất tạo phôi ở lợn vẫn còn thấp khi so sánh với ở các loài khác. Một trong những nguyên nhân chủ yếu là trong điều kiện in vitro trứng lợn không phát triển thành thục hoàn thiện như ở các loài khác. Vì vậy, nuôi thành thục in vitro đóng một vai trò đặc biệt quan trọng trong việc sản xuất phôi lợn thụ tinh ống nghiệm. Nuôi thành thục in vitro tạo điều kiện thích hợp cho sự thụ tinh cũng như sự phát triển của phôi. Trong nghiên cứu trước đây, ảnh hưởng của môi trường NCSU-37 và môi trường TCM-199 có bổ sung dịch nang trứng lợn (pFF) hoặc huyết thanh thai bò (FBS) lên sự thành thục in vitro của trứng lợn Landrace thu thập ở Việt Nam đã được so sánh, cho thấy môi trường NCSU-37 bổ sung 10\% of pFF có tỷ lệ trứng đạt đến giai đoạn gian kỳ II cao nhất so với hai loại môi trường TCM-199. Trong nghiên cứu này, những thí nghiệm tiếp theo được tiến hành để xác định đóng góp của môi trường nuôi thành thục lên khả năng thụ tinh và phát triển phôi. Trứng lợn được nuôi trong 3 loại môi trường: NCSU-37 bổ sung 10\% pFF, TCM-199 bổ sung 10\% pFF hoặc $10 \% \mathrm{FBS}$, sau đó được thụ tinh và đưa vào nuôi để theo dõi trạng thái thụ tinh và phát triển phôi. Kết quả cho thấy tỷ lệ tinh trùng xâm nhập và tỷ lệ thụ tinh bình thường ở các nhóm trứng nuôi thành thục bằng môi trường TCM-199 đều cao hơn của nhóm nuôi bằng môi trường NCSU-37. Tỷ lệ phôi phân chia và phôi nang cũng như số tế bào của phôi nang - một tiêu chí để đánh giá chất lượng phôi - đều cao hơn ở các nhóm trứng nuôi thành thục bằng môi trường TCM-199, đặc biệt là nhóm được bổ sung pFF. Do đó, môi trường TCM-199 bổ sung pFF hoặc FBS phù hợp để nuôi thành thục in vitro một cách hiệu quả đối với trứng lợn Landrace thu nhận ở Việt Nam.

Từ khóa: nuôi thành thuc in vitro, TCM-199, NCSU-37, pFF, FBS, thụ tinh ống nghiệm, phát triển phôi 